\title{
STRATEGI PENGEMBANGAN TENAGA KERJA LOKAL DALAM MENINGKATKAN PEREKONOMIAN DAERAH KABUPATEN SUMBAWA BARAT
}

\author{
Muhammad Nursan $^{1}$, Johan Wahyudi' ${ }^{2}$, Akhmad Syafruddin ${ }^{3}$, Anas Pattaray
}

Jurusan Sosial Ekonomi Pertanian, Fakultas Pertanian, Universitas Mataram ${ }^{1)}$

Jurusan Politik, Pemerintahan dan Hubungan Internasional, FISIP, Universitas Brawijaya ${ }^{2}$ Prodi Ilmu Politik, FISIP, Universitas Nusa Cendana3), Program Studi Pengaturan Perjalan, Politeknik Pariwisata

Negeri Lombok ${ }^{4}$

Email korespondensi: mnursan@yahoo.co.id

Naskah diterima: 3 Juli 2021 Direvisi: 27 Juli 2021 Disetujui terbit: 28 Agustus 2021

\begin{abstract}
ABSTRAK
Kabupaten Sumbawa Barat (KSB) merupakan salah satu wilayah dengan potensi sumber daya alam melimpah terutama pada sektor pertambangan. Hal ini menyebabkan tingginya arus masuk tenaga kerja pendatang sehingga berdampak pada penyerapan jumlah tenaga kerja lokal dan adanya persaingan mendapatkan pekerjaan. Penelitian ini bertujuan untuk memberikan gambaran kondisi internal dan eksternal tenaga kerja lokal dan merumuskan strategi pengembangan tenaga kerja lokal dalam meningkatkan perekonomian daerah KSB. Penelitian ini termasuk penelitian deskriptif. Penentuan responden dilakukan secara purposive sampling sebanyak 40 responden. Data yang dikumpulkan dianalisis menggunakan analisis deskriptif dan analisis SWOT. Hasil penelitian menunjukkan bahwa kondisi internal tenaga kerja lokal KSB masih lebih besar faktor kelemahan dibandingkan dengan faktor kekuatan, sedangkan untuk kondisi faktor eksternal masih lebih besar faktor peluang dibandingkan faktor ancaman. Strategi pengembangan tenaga kerja lokal dalam meningkatkan perekonomian daerah KSB adalah strategi WO atau Turn Around yang meliputi; meningkatkan keterampilan tenaga kerja pada sektor formal maupun informal terutama bagi tenaga kerja lokal, meningkatkan sarana dan prasarana serta SDM penunjang BLK untuk pelatihan dan peningkatan keterampilan usaha tenaga kerja lokal pada berbagai sektor, mempercepat pelayanan dan aturan investasi usaha di KSB sehingga dapat menyerap tenaga kerja lokal lebih banyak.
\end{abstract}

Kata kunci: Analisis SWOT, Strategi pengembangan, Kabupaten Sumbawa Barat, Tenaga Kerja Lokal

\begin{abstract}
West Sumbawa Regency (KSB) is one area with abundant natural resource potential, especially in the mining sector. This causes a high influx of migrant workers so that it has an impact on the absorption of the number of local workers and there is competition for jobs. This study aims to provide an overview of the internal and external conditions of the local workforce and formulate strategies for developing local workers in improving the regional economy of KSB. This research includes descriptive research. Determination of respondents was done by purposive sampling as many as 40 respondents. The data collected were analyzed using descriptive analysis and SWOT analysis. The results showed that the internal condition of the local workforce in KSB was still greater than the weakness factor compared to the strength factor, while for the external factor the opportunity factor was still greater than the threat factor. The strategy for developing local workers in improving the regional economy of KSB is the WO or Turn Around strategy which includes improving the skills of workers in the formal and informal sectors,
\end{abstract}


especially for local workers, improving facilities and infrastructure as well as supporting human resources for BLK for training and improving business skills. local workers in various sectors, accelerating services and business investment regulations in KSB so that they can absorb more local workers.

Keywords: SWOT analysis, development strategy, West Sumbawa Regency, local workers

\section{PENDAHULUAN}

Pembangunan perekonomian daerah maupun nasional salah satunya ditentukan oleh faktor ketenagakerjaan. Tenaga kerja merupakan motor penggerak dalam pembangunan karena berfungsi sebagai sumber daya produksi serta mendistribusikan barang dan jasa, dan sebagai sasaran pengembangan pasar sehingga dengan adanya fungsi tersebut maka pertumbuhan ekonomi akan dapat berlangsung secara terus-menerus terutama dalam jangka panjang Oleh karena itu, ketenagakerjaan menjadi sumberdaya penting terutama dalam memajukan usaha perekonomian dan pembangunan suatu negara (Adam, 2016; Soleh, 2017). Selain itu, tenaga kerja juga menjadi faktor kunci penentu daya saing perekonomian bersama faktor lainnya seperti infrastruktur dan governance (World Bank, 2010; APO, 2015; OECD, 2015). Penelitian Emsina (2014) juga menyatakan bahwa faktor tenaga kerja memiliki korelasi yang cukup kuat dengan daya saing perekonomian.

Indonesia saat ini menduduki posisi empat besar dunia untuk jumlah penduduk di dunia dan hal ini selaras dengan potensi jumlah tenaga kerja yang besar pula. Menurut World Bank (2013), Indonesia menduduki peringkat keempat tertinggi di dunia dalam hal jumlah tenaga kerja dan terus mengalami peningkatan dari tahun ke tahun seiring dengan bertambahnya penduduk. Pada tahun 2018 jumlah penduduk Indonesia yang masuk usia produktif yaitu sebesar 193.55 juta orang dan yang masuk ke dalam angkatan kerja sebesar 133.94 juta orang dimana mengalami kenaikan sebesar 2.39 juta orang dibanding pada tahun sebelumnya (BPS, 2018). Besarnya ketersediaan tenaga kerja atau angkatan kerja tersebut tentu harus diimbangi oleh adanya usaha penyediaan lapangan kerja yang cukup agar tidak menimbulkan permasalahan pengangguran yang dapat menghambat pertumbuhan ekonomi (Faedlulloh, 2015; Wijayanto \& Ode, 2019). Selain itu juga, rendahnya keterampilan kerja dan pendidikan masih menjadi permasalahan tenaga kerja di Indonesia (Nuraeni, 2020). Oleh karena itu, untuk mengimbangi dan mengatasi 
permasalahan tersebut kehadiran dan peran negara dalam hal peningkatan keterampilan dan peluang kerja bagi tenaga kerja tentu sangat diperlukan (Ruyter et al., 2019).

Kabupaten Sumbawa Barat merupakan salah satu kabupaten dengan pertumbuhan ekonomi daerah yang sangat pesat di Provinsi Nusa Tenggara Barat. Hal ini dapat dilihat dari banyaknya pembangunan sarana dan prasarana yang dilakukan baik oleh pemerintah daerah maupun pihak swasta. Tingginya tingkat pembangunan ini juga tidak terlepas dari tingginya tingkat pertumbuhan ekonomi khususnya dari sektor pertambangan, dimana penyediaan lapangan pekerjaan dan kesempatan kerja menjadi salah satu faktor utamanya. Penyediaan lapangan kerja dan kesempatan kerja yang tidak diimbangi dengan peningkatan keterampilan tenaga kerja khususnya tenaga kerja lokal, masih menjadi permasalahan ketenagakerjaan di Kabupaten Sumbawa Barat sehingga tenaga kerja lokal belum sepenuhnya bisa diserap oleh pasar kerja. Menurut World Bank \& IFC (2012), kurangnya tenaga kerja terdidik menjadi salah satu faktor utama kurangnya penyerapan tenaga kerja di Indonesia disamping infrastruktur yang buruk dan kebijakan yang masih berbelit-belit.
Untuk mengatasi permasalahan tenaga kerja lokal di Kabupaten Sumbawa Barat maka perlu strategi dan gambaran umum mengenai kondisi internal dan eksternal ketenagakerjaan lokal untuk mencapai keseimbangan penyediaan lapangan kerja dan kualitas tenaga kerja lokal dalam rangka meningkatkan daya saing dan produktivitas tenaga kerja lokal. Dengan adanya peningkatan produktivitas tenaga kerja khususnya tenaga kerja lokal maka akan menjadi mesin penggerak utama pertumbuhan ekonomi (World Bank, 2010; Skjaerlund, 2014; OECD, 2015).

Berdasarkan uraian di atas maka penelitian ini bertujuan untuk memberikan gambaran mengenai kondisi internal dan eksternal tenaga kerja lokal serta merumuskan strategi pengembangan tenaga kerja lokal dalam meningkatkan perekonomian daerah Kabupaten Sumbawa Barat.

\section{METODE PENELITIAN}

Kabupaten Sumbawa Barat merupakan wilayah penelitian ini yang dipilih secara purposive sampling karena merupakan wilayah industri pertambangan yang sangat diminati oleh pencari kerja dan masih mengalami masalah ketenagakerjaan lokal. Metode deskriptif dengan pendekatan 
kualitatif dan kuantitatif dipilih sebagai metode penelitian (Sugiono, 2017). Pengumpulan data dilakukan dengan teknik survei menggunakan kueisoner untuk mewawancarai responden penelitian yang berjumlah 40 orang yang terdiri atas unsur pemerintah Dinas Tenaga Kerja Kabupaten Sumbawa Barat, Perusahaan pada BUMN/BUMD, PT AMNT, PJTKI dan Perusahaan yang berkenaan dengan jasajasa tenaga kerja lokal dengan melakukan interview langsung pelaku-pelaku tenaga kerja lokal, baik pelaku di sektor privat, formal maupun non formal serta Serikat Pekerja / Serikat, Buruh / Tenaga Kerja Lokal di wilayah Sumbawa Barat. Data dari hasil wawancara kemudian dianalisis secara deskriptif dan menggunakan analisis SWOT yaitu analisis terhadap faktor internal yang terdiri atas kekuatan (Strenghts) dan Kelemahan (Weaknesses) dan faktor eksternal berupa potensi (Opportunities) dan Ancaman (Threats) yang terdapat dalam perusahaan (Rangkuti, 2015). Analisis SWOT ini juga sering digunakan pada beberapa penelitianpenelitian sebelumnya terkait studi perumusan stategi pengembangan di Kabupaten Sumbawa Barat seperti penelitian Ariani \& Nursan (2017), Nursan \& Utama, (2019) dan Nursan \& Sukarne (2021).

\section{HASIL DAN PEMBAHASAN}

\section{Gambaran Ketenagakerjaan Kabupaten}

\section{Sumbawa Barat}

Kabupaten Sumbawa Barat (KSB) merupakan salah satu kabupaten yang ada di Wilayah Provinsi Nusa Tenggara Barat. Kabupaten ini dikenal dengan salah satu daerah pertambangan emas di Indonesia sehingga tidak heran pertumbuhan ekonomi KSB sangat tinggi. Dengan beroperasinya perusahaan pertambangan emas tersebut maka menyebabkan arus tenaga kerja yang datang ke KSB juga sangat tinggi dan bersaing dengan tenaga kerja lokal dalam mencari pekerjaan. Jumlah angkatan kerja di KSB dari tahun ke tahun selalu mengalami peningkatan dimana pada tahun 2020 jumlah angkatan kerja KSB sebanyak 78.582 jiwa atau 94,50 persen, dan Tingkat Partisipasi Angkatan Kerja (TPAK) sebesar 69,73 persen, jika dibandingkan dengan tahun 2019 angka ini mengalami peningkatan sebesar 0.98 persen. Kemudian untuk jumlah pengangguran di KSB dari tahun ke tahun cenderung stabil dan menurun dimana pada tahun yang sama jumlah pengangguran sebesar 5,50 persen menurun 0.02 persen dibandingkan tahun 2019 (BPS KSB, 2021).

Penduduk di KSB dari hasil survei angkatan kerja nasional pada tahun 2020, 
jika dilihat dari jenis lapangan pekerjaan masih didominasi pada sektor pertanian yaitu sebesar 28,76 persen, kemudian dikuti oleh sektor manufaktur 17, 43 persen dan sisanya terbagi pada sektor lainnya sebesar 53,81 persen. Kemudian dari data tersebut dapat diketahui juga bahwa penduduk KSB yang bekerja pada sektor informal sebesar 56.69 persen sedangkan sektor formal sebesar 43,31 persen (BPS, 2020).

\section{Identifikasi Faktor Internal dan Eksternal Ketenagakerjaan Lokal}

Perumusan strategi menggunakan analisis SWOT dilakukan dengan terlebih dahulu melakukan identifikasi terhadap faktor internal dan eksternal ketenagakerjaan lokal di Kabupaten Sumbawa Barat. Pada umumnya terdapat 2 faktor yang perlu diidentifikasikan dalam analisis SWOT yaitu faktor internal yang meliputi kekuatan dan kelemahan, kemudian peluang dan ancaman yang merupakan faktor eksternal (Rangkuti, 2015). Pada penelitian ini telah diperoleh hasil identifikasi faktor kekuatan dan kelemahan yang termasuk ke dalam faktor internal ketenagakerjaan lokal di Kabupaten Sumbawa Barat. Dimana faktor kekuatan adalah faktor atau sumberdaya serta dukungan yang mendukung pengembangan tenaga kerja lokal di Kabupaten Sumbawa
Barat yaitu meliputi jumlah angkatan kerja produktif yang tinggi di Kabupaten Sumbawa Barat dan adanya dukungan atau program pemerintah daerah berupa pelatihan dan magang untuk tenaga kerja lokal. Kemudian untuk faktor kelemahan yang masih menjadi penghambat atau keterbatasan dalam pengembangan tenaga kerja lokal meliputi masih rendahnya keahlian, keterampilan dan pendidikan tenaga kerja lokal, Balai Latihan Kerja (BLK) belum didukung dengan SDM Pelatihan yang optimal, dan belum memadainya sarana penunjang pelatihan.

Selain faktor internal di atas dalam analisis SWOT juga terdapat faktor ekternal lingkungan. Faktor ekternal ini terdiri atas faktor peluang dan faktor ancaman. Faktor peluang dapat diartikan sebagai keadaan yang menguntungkan atau kebijakan yang membuat ketenagakerjaan lokal dapat berkembang atau meningkat seperti potensi dan kondisi SDA terutama pertambangan, pertanian dan pariwisata yang melimpah dan adanya investasi usaha yang kondusif di KSB merupakan peluang pengembangan tenaga kerja lokal di Kabupaten Sumbawa Barat. Kemudian untuk faktor ancaman dapat diartikan sebagai kondisi atau keadaan yang tidak menguntungkan bagi pengembangan tenaga kerja lokal karena 
dapat ancaman untuk tenaga kerja lokal. Kabupaten Sumbawa Barat dan masih Adapun faktor ancaman tersebut yang rendahnya kepatuhan perusahaan terhadap berhasil diidentifikasi yaitu adanya peraturan ketenagakerjaan. kehadiran tenaga kerja pendatang di

Tabel 1. Matriks SWOT Pengembangan Tenaga Kerja Lokal di Kabupaten Sumbawa Barat

\begin{tabular}{|c|c|c|}
\hline Faktor-faktor Internal & $\begin{array}{l}\text { Strenghts: } \\
\text { Jumlah angkatan kerja } \\
\text { produktif yang tinggi. } \\
\text { Adanya dukungan } \\
\text { pemerintah untuk pelatihan } \\
\text { dan magang. }\end{array}$ & $\begin{array}{l}\text { Weaknesses: } \\
\text { Rendahnya keahlian, } \\
\text { keterampilan dan } \\
\text { pendidikan tenaga kerja } \\
\text { lokal. } \\
\text { BLK belum didukung } \\
\text { dengan SDM Pelatihan yang } \\
\text { optimal. } \\
\text { Belum memadainya sarana } \\
\text { penunjang pelatihan. }\end{array}$ \\
\hline Faktor-faktor Eksternal & & \\
\hline $\begin{array}{l}\text { Opportunities: } \\
\text { Potensi dan kondisi SDA } \\
\text { terutama pertambangan dan } \\
\text { pariwisata yang melimpah. } \\
\text { Adanya investasi usaha yang } \\
\text { kondusif di KSB }\end{array}$ & $\begin{array}{l}\text { Strategi (SO): } \\
\text { Meningkatkan pelatihan dan } \\
\text { magang angkatan kerja terkait } \\
\text { pengelolaan potensi sumber } \\
\text { daya alam, pertambangan, } \\
\text { pertanian pariwisata dan } \\
\text { sektor lainnya. } \\
\text { Menerapkan kebijakan } \\
\text { perizinan investasi satu pintu } \\
\text { dan pelayanan prima. }\end{array}$ & $\begin{array}{l}\text { Strategi (WO): } \\
\text { Meningkatkan keterampilan } \\
\text { tenaga kerja pada sektor } \\
\text { formal maupun informal, } \\
\text { terutama bagi tenaga kerja } \\
\text { lokal. } \\
\text { Meningkatkan sarana dan } \\
\text { prasarana serta SDM } \\
\text { penunjang BLK untuk } \\
\text { pelatihan dan peningkatan } \\
\text { keterampilan usaha tenaga } \\
\text { kerja lokal pada berbagai } \\
\text { sektor. } \\
\text { Mempercepat pelayanan dan } \\
\text { aturan investasi di KSB } \\
\text { sehingga dapat menyerap } \\
\text { tenaga kerja lokal lebih } \\
\text { banyak. }\end{array}$ \\
\hline
\end{tabular}




\begin{tabular}{|c|c|c|}
\hline $\begin{array}{l}\text { Threats: } \\
\text { Kehadiran tenaga kerja } \\
\text { pendatang. } \\
\begin{array}{l}\text { Rendahnya } \quad \text { kepatuhan } \\
\text { perusahaan } \\
\text { peraturan ketenagakerjaan. }\end{array}\end{array}$ & $\begin{array}{l}\text { Strategi (ST): } \\
\text { Menyiapkan aturan } \\
\text { ketenagakerjaan } \\
\text { berpihak pada tenaga kerja } \\
\text { lokal. } \\
\text { Menyiapkan regulasi yang } \\
\text { tegas terkait ketenagakerjaan } \\
\text { bagi perusahaan yang } \\
\text { beroperasi di Sumbawa Barat. }\end{array}$ & $\begin{array}{l}\text { Strategi (WT): } \\
\text { Kerja sama pemerintah } \\
\text { dengan pihak swasta dalam } \\
\text { meningkatkan keterampilan } \\
\text { ketenagakerjaan lokal. }\end{array}$ \\
\hline
\end{tabular}

\section{Analisis Faktor Strategis Internal}

Analisis faktor-faktor strategis internal dilakukan untuk mengetahui seberapa besar kekuatan dan kelemahan dari lingkungan faktor internal (Rangkuti, 2015). Hasil analisis tersebut dapat berupa faktor kekuatan lebih dominan dibandingkan faktor kelemahan atau sebaliknya justru faktor kelemahan lebih mendominasi daripada faktor kekuatan. Secara rinci mengenai analisis faktor strategis internal pengembangan tenaga kerja lokal di Kabupaten Sumbawa Barat disajikan pada tabel matrix Internal Strategic Faktor Analysis Summary (IFAS) berikut ini:

Tabel 2. Hasil IFAS Pengembangan Tenaga Kerja Lokal di Kabupaten Sumbawa Barat

\begin{tabular}{lccc}
\hline$\quad$ Faktor-Faktor Strategi Internal & Bobot & Rating & $\begin{array}{c}\text { Bobot } \\
\text { X Rating }\end{array}$ \\
\hline Kekuatan & & & \\
Jumlah angkatan kerja produktif yang tinggi & 0.12 & 3 & 0.39 \\
$\begin{array}{l}\text { Dukungan pemerintah daerah } \\
\text { Kelemahan }\end{array}$ & 0.12 & 3 & 0.37 \\
Rendahnya keahlian, keterampilan dan pendidikan tenaga & 0.09 & 2 & 0.77 \\
kerja lokal & & & \\
BLK belum didukung secara optimal & 0.13 & 4 & 0.48 \\
Belum memadainya sarana penunjang pelatihan & 0.10 & 3 & 0.26 \\
\hline Sumbu X (Kekuatan - Kelemahan) & & & 0.94 \\
\hline
\end{tabular}

Berdasarkan hasil IFAS diperoleh bahwa nilai dari faktor strategis internal yang berupa faktor kekuatan sebesar 0.77 dan faktor kelemahan sebesar 0.94. Dari nilai tersebut diperoleh bahwa faktor stategis internal yang berupa faktor kelemahan 
lebih dominan daripada faktor kekuatan dengan selisih sebesar -0.17. Oleh karena itu, dalam rangka pengembangan tenaga kerja lokal dalam meningkatkan perekonomian daerah Kabupaten Sumbawa Barat jika dilihat dari analisis faktor internal perlu dilakukan dengan meminimalisir kelemahan untuk mengoptimalkan kekuatan yang dimiliki.

\section{Analisis Faktor Strategis Eksternal}

Analisis faktor-faktor strategis ekternal dilakukan untuk mengetahui seberapa besar nilai faktor eksternal yang

Tabel 3. Hasil EFAS Pengembangan Tenaga Kerja Lokal di Kabupaten Sumbawa Barat

\begin{tabular}{|c|c|c|c|}
\hline Faktor-Faktor Strategi Eksternal & Bobot & Rating & $\begin{array}{l}\text { Bobot } \\
\text { X Rating }\end{array}$ \\
\hline \multicolumn{4}{|l|}{ Peluang } \\
\hline \multirow{3}{*}{$\begin{array}{l}\text { Potensi dan kondisi SDA terutama pertambangan, pertanian, } \\
\text { pariwisata dan sektor lainnya yang melimpah } \\
\text { Adanya investasi usaha yang kondusif di KSB }\end{array}$} & 0.13 & 4 & 0.47 \\
\hline & & & \\
\hline & 0.11 & 3 & 0.33 \\
\hline \multicolumn{4}{|l|}{ Ancaman } \\
\hline Kehadiran tenaga kerja pendatang & 0.10 & 3 & 0.29 \\
\hline \multirow[t]{2}{*}{$\begin{array}{l}\text { Rendahnya kepatuhan perusahaan terhadap peraturan } \\
\text { ketenagakerjaan }\end{array}$} & 0.09 & 2 & 0.20 \\
\hline & & & 0.49 \\
\hline Sumbu Y (Peluang - Ancaman) & & & 0.31 \\
\hline
\end{tabular}

Berdasarkan hasil EFAS diperoleh bahwa nilai dari faktor strategis eksternal yang berupa faktor peluang sebesar 0.80 dan faktor kelemahan sebesar 0.49. Dari nilai tersebut diperoleh bahwa faktor stategis internal yang berupa faktor peluang lebih dominan daripada faktor ancaman dengan selisih sebesar 0.31 . Oleh karena itu, dalam rangka pengembangan tenaga kerja lokal dalam meningkatkan perekonomian daerah 
Kabupaten Sumbawa Barat jika dilihat dari analisis faktor eksternal perlu dilakukan dengan mengoptimalkan peluang yang ada untuk menghindari ancaman.

\section{Strategi Pengembangan Tenaga Kerja Lokal dalam Meningkatkan Perekonomian Daerah Kabupaten Sumbawa Barat} Dalam menyusun strategi pengembangan tenaga kerja lokal dalam meningkatkan perekonomian daerah Kabupaten Sumbawa Barat, maka perlu dibuat matriks space. Matrix spase ini dapat digambarkan berdasarkan hasil analisis pada tabel IFAS dan EFAS berikut ini:

- Faktor Kekuatan (Strenghts) - Kelemahan $($ Weaknesses $)=0.77-0.94=-0.17$

- Faktor Peluang (Opportunities) - Ancaman (Threats) $=0.80-0.49=0.31$

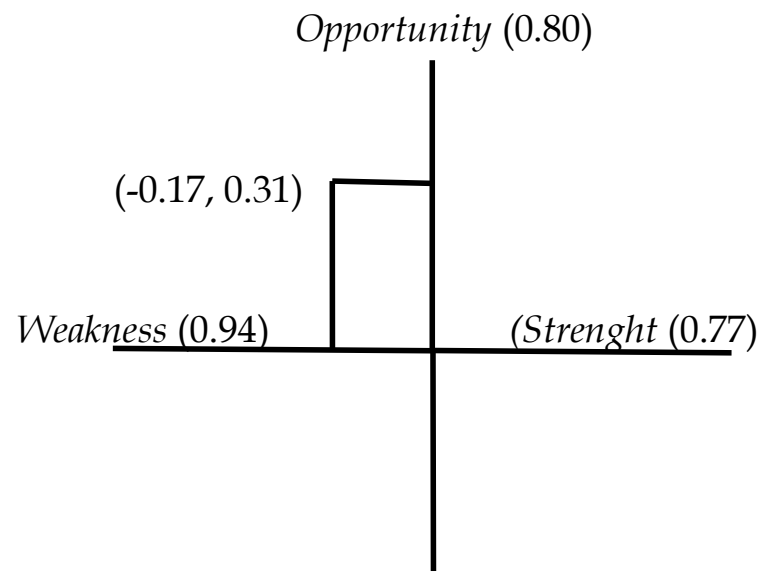

Threat (0.49)

Gambar 1. Matrik Space

Hasil analisis matrix space SWOT menunjukkan bahwa strategi pengembangan tenaga kerja lokal dalam meningkatkan perekonomian daerah Kabupaten Sumbawa Barat adalah strategi W-O (Weakness-Opportunity) yaitu strategi yang meminimalkan kelemahan yang dimiliki untuk meraih peluang atau Turn Around Strategy. Adapun strategi Turn Around Strategy atau Strategi W-O tersebut meliputi:

1. Meningkatkan keterampilan tenaga kerja pada sektor formal maupun informal, terutama bagi tenaga kerja lokal.

2. Meningkatkan sarana dan prasarana serta SDM penunjang BLK untuk pelatihan dan peningkatan keterampilan usaha tenaga kerja lokal pada berbagai sektor.

3. Mempercepat pelayanan dan aturan investasi usaha di KSB sehingga dapat menyerap tenaga kerja lokal lebih banyak

\section{KESIMPULAN DAN SARAN}

\section{Kesimpulan}

Berdasarkan hasil dan pembahasan pada penelitian strategi pengembangan tenaga kerja lokal dalam meningkatkan perekonomian daerah Kabupaten Sumbawa Barat ini dapat disimpulkan bahwa: 
1. Kondisi faktor internal pengembangan tenaga kerja lokal dalam meningkatkan perekonomian daerah Kabupaten Sumbawa Barat masih lebih besar faktor kelemahan dibandingkan dengan faktor kekuatan, sedangkan untuk kondisi faktor eksternal masih lebih besar faktor peluang dibandingkan faktor ancaman.

2. Strategi pengembangan tenaga kerja lokal dalam meningkatkan perekonomian daerah Kabupaten Sumbawa Barat adalah strategi W-O (Weakness-Opportunity) atau strategi Turn Around adapun yang termasuk strategi Turn Around tersebut yaitu meningkatkan keterampilan tenaga kerja pada sektor formal maupun informal, terutama bagi tenaga kerja lokal, meningkatkan sarana dan prasarana serta SDM penunjang BLK untuk pelatihan dan peningkatan keterampilan usaha tenaga kerja lokal pada berbagai sektor, mempercepat pelayanan dan aturan investasi usaha di KSB sehingga dapat menyerap tenaga kerja lokal lebih banyak.

\section{Saran}

Berdasarkan kesimpulan di atas, dalam rangka pengembangan tenaga kerja lokal Kabupaten Sumbawa Barat dapat disarankan agar pemerintah daerah terus meningkatkan keterampilan tenaga kerja lokal melalui pelatihan maupun magang bagi tenaga kerja lokal baik secara kuantitas maupun kualitas, kemudian memperbaiki sarana dan prasarana penunjang pelatihan dengan melengkapi SDM pelatih profesional di BLK.

\section{DAFTAR PUSTAKA}

Adam, L. (2016). Membangun Daya Saing Tenaga Kerja Indonesia Melalui Peningkatan Produktivitas. Jurnal Kependudukan Indonesia, 11(2), 71-84.

APO. (2015). APO Productivity Data Book. Asian Productivity Organization. Ariani, Z., \& Nursan, M. (2017). Strategi Pengembangan Desa Mantar Sebagai Kawasan Desa Wisata di Kabupaten Sumbawa Barat. Biologi Tropis, 17(2), 58-68.

BPS. (2018). Keadaan Ketenagakerjaan Indonesia Februari 2018. Badan Pusat Statistik Republik Indonesia.

BPS. (2020). Keadaan Angkatan Kerja di Indonesia Agustus 2020. Badan Pusat Statistik Republik Indonesia.

BPS KSB. (2021). Statistik Daerah Kabupaten Sumbawa Barat Tahun 2021. Badan Pusat Statistik Kabupaten Sumbawa Barat. 
Emsina, A. . (2014). Labor Productivity, Economic Growth, and Global Competitive in Post Crisis Period. Social and Behavioural Sciences, 156(2), 317-321.

Faedlulloh, D. (2015). Homo Cooperativus:

Redefinisi Makna Manusia Indonesia. Masa Depan Manusia Indonesia: Prospek Dan Pemberdayaan.

Nuraeni, Y. (2020). Analisis Terhadap Undang Undang Ketenagakerjaan Indonesia Dalam Menghadapi Tantangan Revolusi Industri 4.0. Jurnal Ketenagakerjaan, $\quad 5(1), \quad 1-12$. https://doi.org/https://doi.org/10.47 198/naker.v15i1.47

Nursan, M., \& Sukarne. (2021). Strategi Pengembangan Agribisnis Ternak Sapi di Kabupaten Sumbawa Barat. Jurnal Cemara, 18(2), 18-29.

Nursan, M., \& Utama, F. A. (2019). Strategi Pengembangan Badan Usaha Milik Desa (Bumdes) Berbasis Pertanian Di Kabupaten Sumbawa Barat. 8(2), 67-78. https://doi.org/http://dx.doi.org/10. 26418/j.sea.v8i2.37726

OECD. (2015). The Future of Productivity. Organization for Economic Cooperation and Development.

Rangkuti, F. (2015). Analisis SWOT. PT Gramedia Pustaka Utama.
Ruyter, D., Alex, Brown, M., \& Burgess, J. (2019). Gig Work and the Fourth Industrial Revolution: Conceptual and Regulatory Challenges. Journal of International Affairs, 1, 37-50.

Skjaerlund, G. (2014). Training Supply Situation Report on Non-Formal Training. TNP2K-World Bank.

Soleh, A. (2017). Masalah Ketenagakerjaan dan Pengangguran di indonesia. Jurnal Ilmiah Cano Ekonomos, 6(2), 83-92.

Sugiono. (2017). Metode Penelitian Kuantitatif, Kualitatif, dan RED. Alfabeta.

Wijayanto, H., \& Ode, S. (2019). Dinamika Permasalahan Ketenagakerjaan dan Pengangguran di Indonesia. Jurnal Ilmiah Administrasi Publik Dan Pembangunan, 10(1), 1-8.

World Bank. (2010). Stepping Up Skills, For More Jobs and Higher Productivity. The World Bank.

World Bank, \& IFC. (2012). Doing Bussines di Indonesia 2012: Membandingkan Kebijakan Usaha di 20 Kota dan 183 Perekonomian. Bank Dunia dan International Finance Corporation. 